\title{
Methanogenesis in Sediments of the Polluted Lower Reaches of the Tama River
}

\author{
Susumu TAKII
}

\begin{abstract}
Seasonal changes of methanogenesis were studied in sediments of three stations along the water course in the polluted lower reaches of the Tama River, Japan. Methanogenesis was the highest at the upper freshwater station and decreased near the river mouth, in accordance with increasing concentration of sulfate in interstitial water. At all stations methanogenesis increased from spring to summer and decreased in winter except for once at the lowest station. The sediment layer which showed the highest activity tended to become deeper downstream. Effects of additions of substrates or inhibitors on methanogenesis in sediment slurries suggested that methanogenesis was competitively inhibited by sulfate reduction in sediments containing high sulfate concentrations, but the degree of the inhibition decreased in sediments with low sulfate concentration.
\end{abstract}

Key words : seasonal change, tidal river, methanogenic bacteria, sulfate-reducing bacteria.

\section{Introduction}

Organic matter in river water tends to settle in the lower reaches because of the decrease in current velocity and mixing of river water with seawater (salting out) (OGura, 1978; Scholkovitz, 1978). Since the microbial decomposition of organic deposits rapidly consumes dissolved oxygen, the bottom sediments may often become anaerobic, especially in a polluted river. In such environments, anaerobic bacteria may cotribute significantly to the overall mineralization of organic matter. Methanogenesis and sulfate reduction are very important in the final step of anaerobic mineralization and as scavengers for $\mathrm{H}_{2}$, which enhance the activity if fermentative bacteria through lowering in situ $\mathrm{H}_{2}$ concentration (interspecies $\mathrm{H}_{2}$ transfer) (Nedwell, 1984; LaANBRoek and VeldKamp, 1982; IANNOTTI et al., 1973).

Methanogenesis is generally the dominating process in freshwater sediments where a limited supply of sulfate suppresses sulfate reduction
(Smith and Klug, 1981; ZaISS, 1981; INGVoRsen and ВRоск, 1982; Phelps and Zeikus, 1985). On the contrary, sulfate-reducing bacteria (SRB) outcompete methanogenic bacteria in sulfaterich marine sediments (JøRGENSEN, 1977; Oremland and Tayler, 1978; Mountfort et al., 1980; Sørensen et al., 1981; Senior et al., 1982), as a consequence of the higher affinity to common electron donors such as $\mathrm{H}_{2}$ and acetate, and higher energy and growth yields than the methanogenic bacteria (Lovley et al., 1982; Schönheit et al., 1982; KRISTJANSSON et al., 1982; Lupton and Zeikus, 1984; Robinson and Tiedje, 1984 ; WARD and WINFREY, 1985).

In the lower reaches and estuary of a river, sulfate supply greatly varies from time to time in response to tidal cycle, and from place to place according to the distance from the river mouth. In such environments, it is very interesting to study the interaction between methanogenesis and sulfate reduction, although there have been very tew studies (Sayama and KURIHARA, 1984). 
The purpose of the present study is to survey the seasonal change in methanogenesis of sediments at three stations along the water course of polluted lower reaches of the Tama River and to evaluate environmental factors controlling methanogenesis.

\section{Materials and methods}

\section{2-1. Sampling}

Sediments and river waters were collected at three stations in the lower reaches of the Tama River which is located in the southwest part of Tokyo Metropolis, Japan. The river has a length of $c a .100 \mathrm{~km}$ and its drainage area, $1,200 \mathrm{~km}^{2}$, has a population of over five million. It is heavily polluted with municipal sewage. Sediment cores were collected at each station with a plexiglas tube (inner diameter, $4.5 \mathrm{~cm}$ and $30 \mathrm{~cm}$ long).

Station 1 is about $13.5 \mathrm{~km}$ upstream from the river mouth and in freshwater region about 200 $\mathrm{m}$ upstream from Chofu Weir, which prevents further penetration of seawater. The sediment of $>4 \mathrm{~cm}$ thick was collected at a water depth of 30 to $50 \mathrm{~cm}$. Black and soft sediment deposited on pebbles nearly always had a surface growth of Spirogyra. Station 2 is at Gasu-bashi, about $10.5 \mathrm{~km}$ upstream from the river mouth. The water depth greatly varied according to the tidal cycle. The sediment on sandy beds was also greatly influenced both quantitatively and qualitatively by the current velocity and particle content in the water. The sediment of $>6$ $\mathrm{cm}$ thick was sampled at low tide from a water depth of 10 to $30 \mathrm{~cm}$. Station 3 is at Daishi-bashi located about $2.5 \mathrm{~km}$ upstream from the river mouth. At this station the water depth greatly changed according to tidal cycle and the current velocity was very low. Sediment samples of $>14 \mathrm{~cm}$ thick were collected at a water depth of about $50 \mathrm{~cm}$ at low tide. The silty sediment was the deepest and the most stable among the three stations. Its color was brown in the upper layer (above $6 \sim 8 \mathrm{~cm}$ ) and black in the deep layer (below $6 \sim 8 \mathrm{~cm}$ ). It always had a large number of nereides. At Stas. 2 and 3, sampling was carried out mostly at low tide of spring tides.
The sediment cores and river waters were transported to the laboratory and used for experiments within five hours. Interstitial water was obtained by centrifuging each $2 \mathrm{~cm}$ thick sediment sample at $10,000 \mathrm{rpm}$ at $5^{\circ} \mathrm{C}$.

\section{2-2. Methanogenic activity of sediments}

Methanogenic activity was measured as the accumulation rate of methane in the headspace of triplicate $100 \mathrm{ml}$ bottles. A sub-core of sediment $(2 \mathrm{~cm}$ thick, $2.3 \mathrm{ml}$ ) was removed from each horizon of the sampled core using $5 \mathrm{ml}$ glass hypodermic syringes with the needle end removed and was transferred into each bottle under oxygen-free nitrogen (OFN). The sediment samples in the bottles were vigorously disintegrated using a glass tube with an OFN nozzle during vortexing to minimize methane release by diffusion from the sediment (KIENE and CAPONE, 1985), and were then incubated at $30^{\circ} \mathrm{C}$ and at in situ temperature after being sealed with double rubber stoppers. Gas samples $(0.2 \mathrm{ml})$ were taken from the headspace within $20 \mathrm{hr}$ incubation and analyzed for methane concentrations. Preliminary experiments showed a linear increase of methane concentration in the headspace for at least $24 \mathrm{hr}$ incubation.

The methanogenesis per sediment surface area was estimated by summing the activity of each $2 \mathrm{~cm}$ thick sediment layer measured at in situ temperature. The depths of surface sediments used for the estimation were $4 \mathrm{~cm}$ for Sta. $1,6 \mathrm{~cm}$ for Sta. 2 and $14 \mathrm{~cm}$ for Sta. 3, according to the minimal depths of sediments deposited at each station.

\section{2-3. Effects on methanogenesis of addi- tions of substrates or inhibitors}

Experiments with sediment slurries were carried out as follows. The surface sediments of 4 and $6 \mathrm{~cm}$ thick from Stas. 1 and 2, respectively, were mixed with twice volumes of deoxygenated distilled water while gassing with OFN, and each $5 \mathrm{ml}$ was distributed into $15 \mathrm{ml}$ serum vials under OFN. In the case of Sta. 3 sediments, the deep $5 \mathrm{~cm}$ thick layer (below 6 or $8 \mathrm{~cm}$ depth) of the sediment was used, because the surface layers had lower methanogenic activities. The sediment sample was mixed with an equal 
volume of $2.25 \% \mathrm{NaCl}$ solution ( $\mathrm{w} / \mathrm{v}$ ) and was distributed as described above. The vials were sealed with butyl rubber stoppers and crimped with aluminum seals after gassing with OFN. Triplicate vials were supplemented with $0.1 \mathrm{ml}$ of the following anaerobic solutions by a syringe through the rubber stoppers to give the following final concentrations: acetate (10 $\mathrm{mM})$, methanol $(10 \mathrm{mM}), \mathrm{Na}_{2} \mathrm{SO}_{4}(20 \mathrm{mM})$ or $\mathrm{Na}_{2} \mathrm{MoO}_{4}(20 \mathrm{mM})$, a specific inhibitor of sulfate reduction (PeCK, 1959; Oremland and TAYLOR, 1978). $\mathrm{H}_{2}$ was added by replacing the headspace with $20 \% \mathrm{H}_{2}: 80 \% \mathrm{CO}_{2}(\mathrm{v} / \mathrm{v})$. After incubation at $30^{\circ} \mathrm{C}$ or in situ temperature for 11 to $19 \mathrm{hr}$, the methane concentration in the headspace was determined by gas chromatography and compared with the control (100\% activity).

\section{2-4. Bacterial numbers}

The number of methanogenic bacteria was estimated by the MPN method using the medium described by CAPPENBERg (1974) supplemented with $30 \%$ rumen fluid (ZAISs, 1981). The sediment sample was diluted with the diluent of Holdeman and Moore (1975) under OFN. Aliquots $(0.5 \mathrm{ml})$ of the dilutions were inoculated by syringes in $5 \mathrm{ml}$ of the medium in $15 \mathrm{ml}$ serum vials plugged with butyl rubber stoppers and crimped with aluminum seals after gassing with $20 \% \mathrm{H}_{2}: 80 \% \mathrm{CO}_{2}$. The growth of methanogenic bacteria was detected by production of methane monitored by gas chromatography in each vial after one-month incubation at $30^{\circ} \mathrm{C}$.

SRB were enumerated by the MPN method using the medium described by Tezuka (1979). The tubes containing the medium were sealed with $2 \%$ melted agar after inoculation. Black colored tubes were counted after 2 weeks incubation at $30^{\circ} \mathrm{C}$.

According to preliminary experiments, methanogenic bacterial counts were higher on the medium with $2.25 \% \mathrm{NaCl}$ added than on the freshwater one; and SRB counts were also higher on seawater medium (TEzUKA, 1979) at Sta. 3. Both the counts were higher on freshwater media at Sta. 2. Then, the $\mathrm{NaCl}$ containing medium and the seawater medium were used for methanogenic bacteria and SRB, respectively, only for samples from Sta. 3, and the freshwater media for those from Stas. 1 and 2 .

\section{2-5. Analytical procedures}

Methane concentrations were determined by a Shimadzu 8A gas chromatograph equipped with a flame ionization detector. Gases were separated on a $2.0 \mathrm{~m}$-glass column packed with Porapack Q 80/100 mesh (Waters Associate, Inc.) and with $\mathrm{N}_{2}$ as the carrier gas. The injector and detector temperature was $100^{\circ} \mathrm{C}$, and the column temperature was $70^{\circ} \mathrm{C}$.

Ignition loss was determined by heating sediment samples dried at $80^{\circ} \mathrm{C}$ overnight in a muffle furnace at $550^{\circ} \mathrm{C}$ for $1 \mathrm{hr}$. Redox potential was measured by inserting a platinum electrode into the core at each depth and reading after $1 \mathrm{hr}$. The value was corrected for temperature.

Temperature and conductivity of river water were measured in the field by a conductivity meter attached with a thermister (Yokogawa SC 51). The value of conductivity was corrected to that at $18^{\circ} \mathrm{C}$. Dissolved oxygen and biochemical oxygen demand (BOD) of river water were determined according to the method of American Public Health Association (1971). Total organic carbon (TOC) in interstitial water was analyzed by a Beckman Model 102D TOC analyzer. Sulfate ion was determined by the colorimetric method using barium chromate (HANYA, 1960). Sulfide in the sediments was trapped into zinc acetate solution by bubbling with OFN under acidic condition, then determined iodometrically (SHIGA, 1983).

\section{Results}

\section{3-1. Physico-chemical characteristics of river waters and sediments}

Table 1 summarizes the water quality and some physico-chemical characteristics of sediments at three stations of the Tama River during two years. As shown by the conductivity of river water, seawater contents in the water increased downstream and fluctuated greatly at Sta. 2. The decrease in average BOD of the water toward the river mouth may have been 


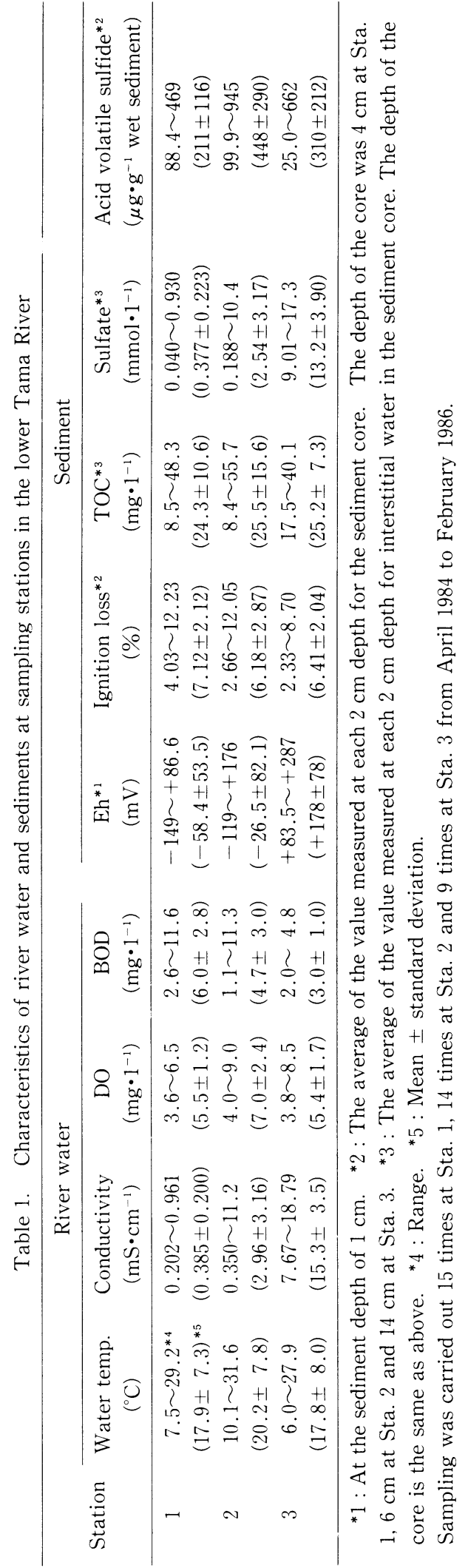

due to dilution of river water with seawater. The value of sediment Eh at a depth of $1 \mathrm{~cm}$ was the lowest at Sta. 1 and the highest at Sta. 3. This agrees with the inverse order of the ignition loss (organic matter content) of the 0 $\sim 2 \mathrm{~cm}$ sediment layer. However, there was no large difference among the three stations in the mean ignition loss of the sediments, when comparison was made for the $0 \sim 4 \mathrm{~cm}$ layer at Sta. 1, the $0 \sim 6 \mathrm{~cm}$ layer at Sta. 2 and the $0 \sim 14 \mathrm{~cm}$ layer at Sta. 3. Mean concentrations of sulfate in interstitial water increased downstream. Acid volatile sulfide in the sediment was higher at Sta. 2 than at Sta. 3 due to its low levels in the shallow sediment layer at Sta. 3 .

\section{3-2. Methanogenic activity of sediments}

Figure 1 shows some typical vertical profiles of methanogenic activity measured at in situ temperature, ignition loss of the sediments and sulfate in interstitial water in summer and winter. The highest activity was found mostly in the surface layer $(0 \sim 2 \mathrm{~cm})$ at Sta. 1 , in the $2 \sim 4 \mathrm{~cm}$ layer at Sta. 2 and in the $12 \sim 14 \mathrm{~cm}$ layer at Sta. 3. This pattern was relatively similar to that of the vertical distribution of organic matter content of sediment except at Sta. 3. There were no distinct differences in vertical distributions of sulfate concentration in interstitial water at either Sta. 1 or 2, but the concentration of sulfate decreased in the $12 \sim 14$ cm layer at Sta. 3.

Figure 2 shows seasonal changes of the methanogenesis per sediment surface area along with temperature and sulfate in interstitial water. Methanogenesis was the highest at Sta. 1 , freshwater station and the lowest at Sta. 3, where salinity was always the highest of the stations. At Sta. 1, the average methanogenesis was $3.37 \mu \mathrm{mol} \cdot \mathrm{cm}^{-2} \cdot \mathrm{d}^{-1}$ and the value was high from spring to summer and low from autumn to winter. At Sta. 2, methanogenesis was very high in May and June 1984, but decreased to lower than $0.5 \mu \mathrm{mol} \cdot \mathrm{cm}^{-2} \cdot \mathrm{d}^{-1}$ from September to March, although the average value $(2.44 \mu \mathrm{mol}$. $\mathrm{cm}^{-2} \cdot \mathrm{d}^{-1}$ ) was not so small compared with that at Sta. 1. The average methanogenesis at Sta. 3 was only $0.096 \mu \mathrm{mol} \cdot \mathrm{cm}^{-2} \cdot \mathrm{d}^{-1}$. It was high in summer and February 1986. 


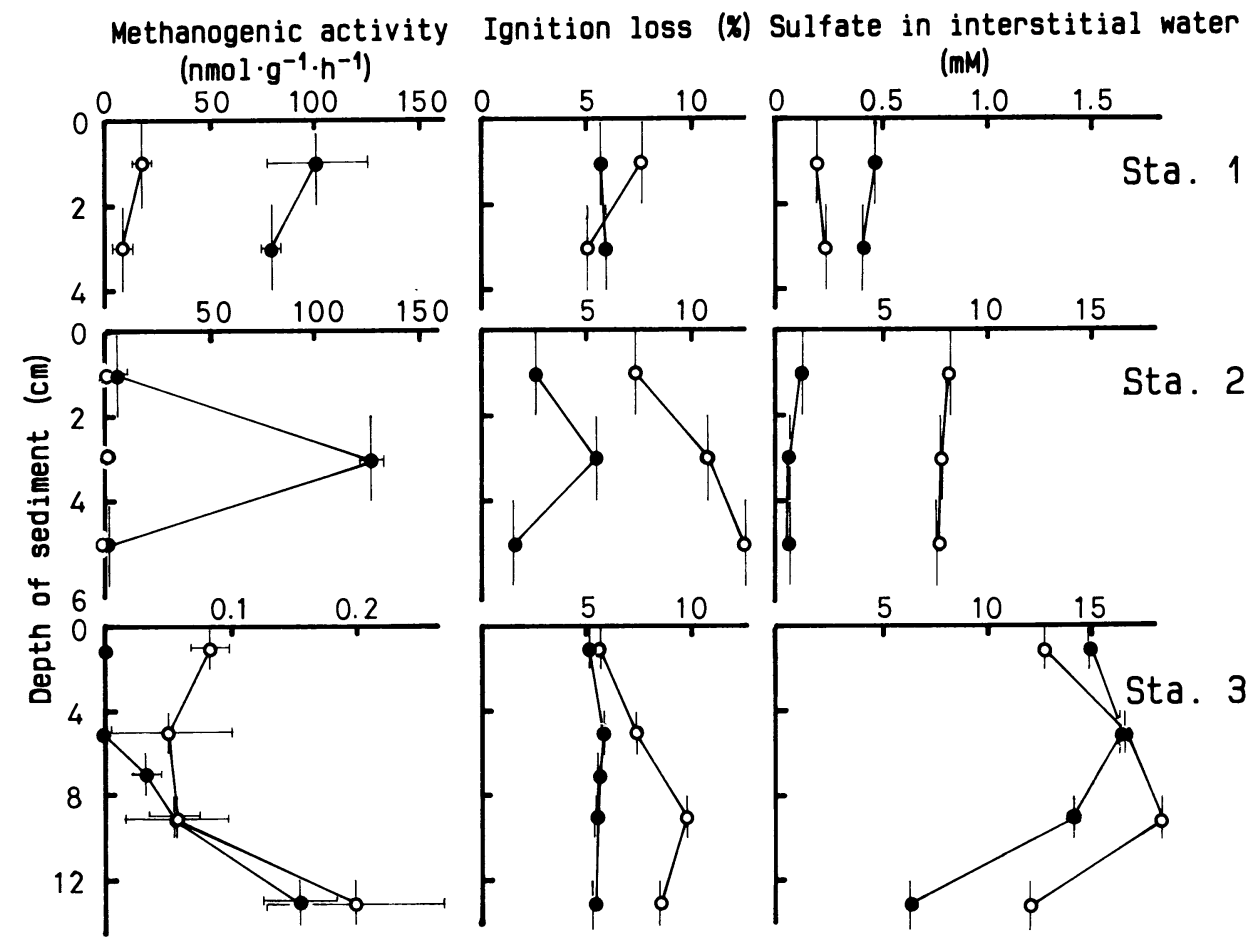

Fig. 1. Typical vertical profiles of methanogenic activity measured at in situ temperature, ignition loss of sediment and sulfate in interstitial water at three stations in the lower Tama River in summer and winter.

Closed circles : summer sample (19 July, 11 July, and 29 August at Stas. 1, 2 and 3, respectively).

Open circles : winter sample (12 February, 8 February, and 26 February at Stas. 1, 2 and 3 , respectively).

Vertical and horizontal bars indicate sampling depth intervals and standard deviations, respectively.

\section{3-3. Effect of addition of substrates or inhibitors on methanogenesis of sedi- ment slurries}

Table 2 summarizes the results on the effects of additions of substrates or inhibitors on methanogenesis of sediment slurries. For comparative reasons the data are expressed in percentages with the control data as $100 \%$.

For sediments from Sta. 1, acetate was the most effective substrate for methanogenesis except the sediment in December 1984. Sulfate addition inhibited methanogenesis about $50 \%$ in summer and autumn but did not in February and March 1985. Stimulation of methanogenesis by molybdate was less than $25 \%$ except for $60 \%$ in October.

Acetate was also more effective for meth- anogenesis than $\mathrm{H}_{2}$ and methanol in Sta. 2 sediments. Strong stimulation of methanogenesis by the acetate addition was observed for both the sediments with low sulfate level (August 1984) and with high sulfate levels (May and October 1985). Inhibition by adding sulfate on methanogenesis was very strong (more than 90\%) for the sediments containing a low concentration of sulfate (in August and October 1984), but negligible or very weak for those with a high sulfate concentration (in November 1984 and May, October and December 1985). Stimulation by molybdate was relatively weak for the former sediments, but more than about two-fold the control level for the latter ones.

For sediments from Sta. 3 where the concen- 


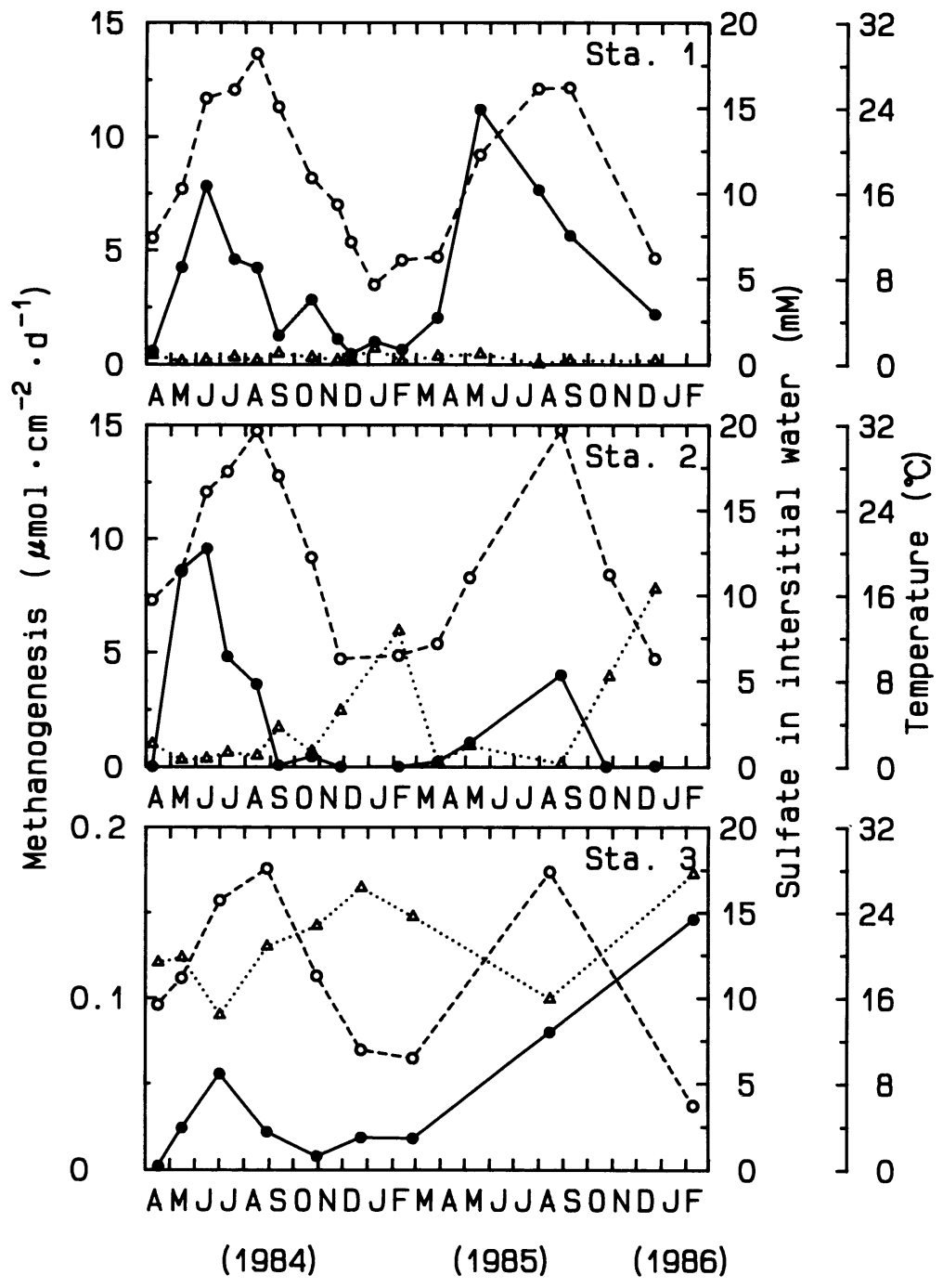

Fig. 2. Seasonal changes in methanogenesis per sediment surface area (closed circles), temperature (open circles), and sulfate in interstitial water (open triangles) at three stations in the lower Tama River. Sediment depth : $4 \mathrm{~cm}, 6 \mathrm{~cm}$, and $14 \mathrm{~cm}$ at Stas. 1, 2, and 3, respectively.

tration of sulfate in interstitial water was always high, addition of sulfate did not inhibit methanogenesis except for the sample in October 1984. Addition of molybdate enhanced methanogenesis more than $40 \%$ of the control except for the sediment on February 1986 which was incubated at $6^{\circ} \mathrm{C}$. For many sediment samples from Sta. 3, methanogenesis was more strongly stimulated by $\mathrm{H}_{2}$ than acetate, different from the other stations. This may suggest that methanogenic bacterial flora at Sta. 3 was different from those at Stas. 1 and 2.

\section{3-4. Bacterial numbers}

The numbers of methanogenic bacteria and SRB are shown in Figure 3. There were almost no difference in numbers of both bacteria between Stas. 1 and 2, but at Sta. 3 they were relatively lower than those at the other two stations. At all stations methanogenic bacteria were generally dominated by SRB throughout the years examined. At Stas. 1 and 2, the number of methanogenic bacteria was higher from spring to summer than in winter, but at Sta. 3 the fluctuations were rather irregular. The sea- 


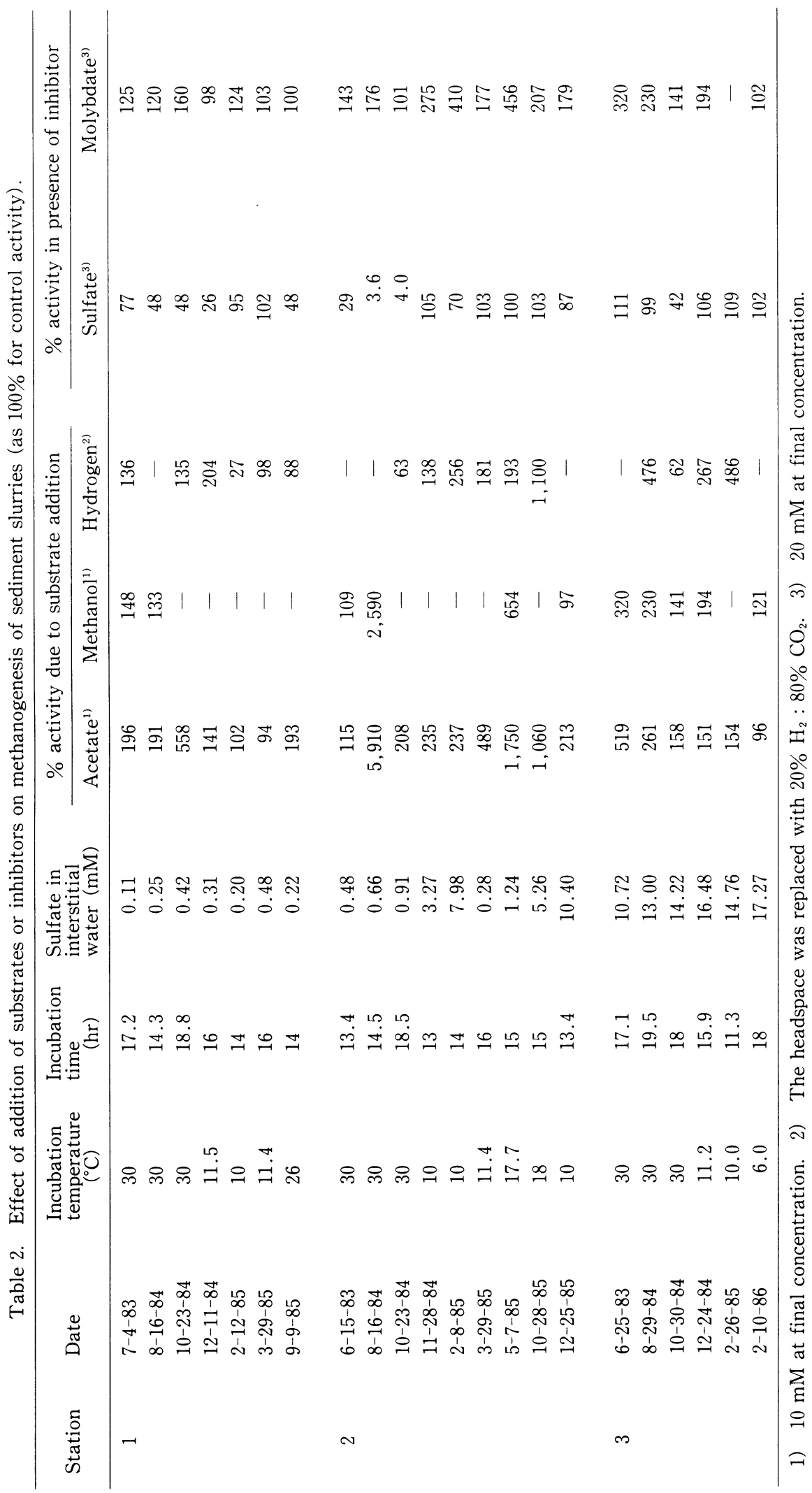



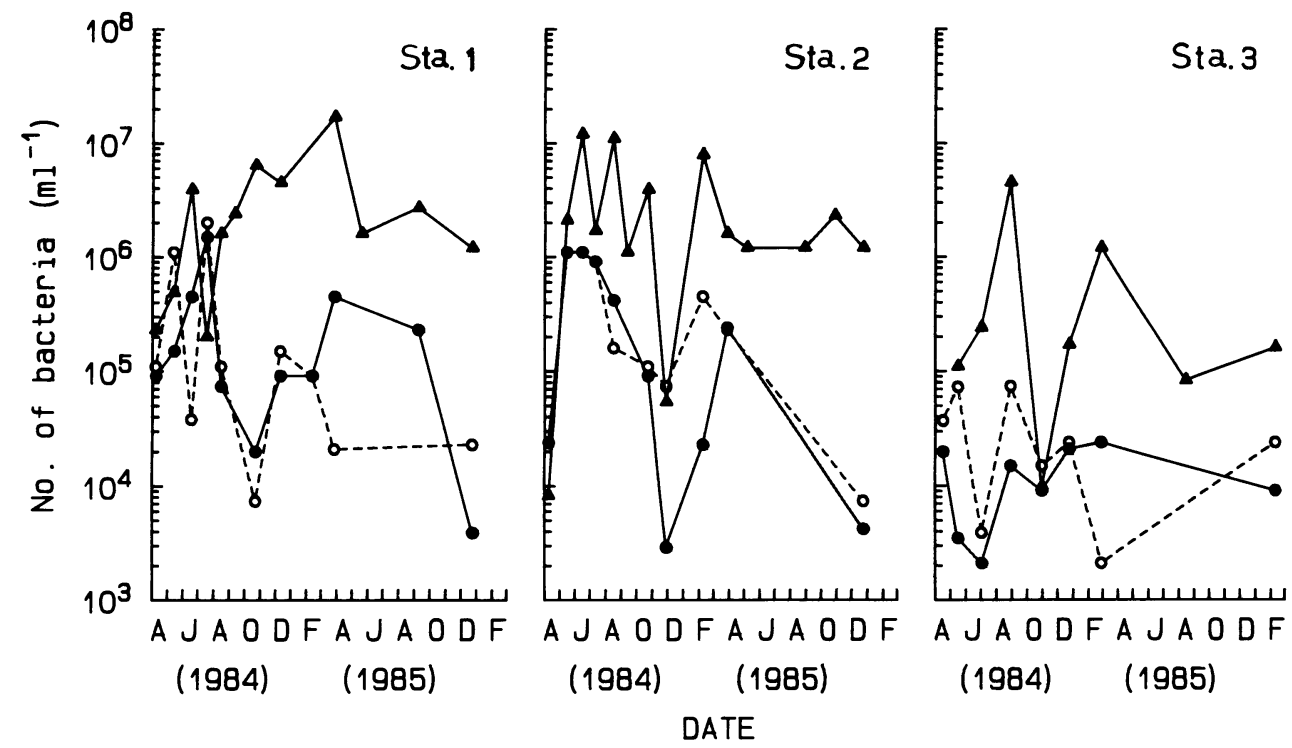

Fig. 3. Seasonal changes of numbers of methanogenic bacteria and sulfate-reducing bacteria in sediments at three stations in the lower Tama River. Closed circles, methanogenic bacteria in the $0 \sim 2 \mathrm{~cm}$ sediment layer; open circles, methanogenic bacteria in the $2 \sim 4 \mathrm{~cm}$ sediment layer at Stas. 1 and 2, and in the $12 \sim 14 \mathrm{~cm}$ layer at Sta. 3 ; closed triangles, sulfate-reducing bacteria in the $0 \sim 2 \mathrm{~cm}$ layer.

sonal variations of SRB were more irregular than those of methanogenic bacteria at three stations. The number of SRB tended to decrease with sediment depth with several exceptions, especially at Sta. 2. On the contrary, methanogenic bacteria were rather uniformly distributed throughout the sediment profile.

\section{Discussion}

In the lower Tama River, methanogenesis in sediment was highest at a freshwater station (Sta. 1) and decreased near the river mouth stations (Stas. 2 and 3) where seawater inflowed. At Sta. 1, the maximum activity at in situ temperature was $0.35 \mu \mathrm{mol} \mathrm{CH}_{4} \cdot \mathrm{g}^{-1}$ dry sediment $\cdot \mathrm{hr}^{-1}$ in the $0 \sim 2 \mathrm{~cm}$ layer. The maximum methanogenesis per sediment area $(0 \sim 4 \mathrm{~cm}$ depth) was calculated to be $1,800 \mathrm{mg} \mathrm{CH}_{4} \cdot \mathrm{m}^{-2}$. $\mathrm{d}^{-1}$ in May 1985. This value is almost equal to the highest methanogenesis ever reported for aquatic sediment $\left(1,600 \mathrm{mg} \mathrm{CH} \mathrm{CH}_{4} \cdot \mathrm{m}^{-2} \cdot \mathrm{d}^{-1}\right.$ for sediment in Lake Erie, HowARD et al, 1971). At Sta. 2, the maximum activity was $0.82 \mu \mathrm{mol}$ $\mathrm{CH}_{4} \cdot \mathrm{g}^{-1} \cdot \mathrm{hr}^{-1}$ in the $2 \sim 4 \mathrm{~cm}$ layer in May 1984 , when the sulfate level in interstitial water was very low. Methanogenesis in the $0 \sim 6 \mathrm{~cm}$ layer fluctuated greatly within the range from 0.065 $\mu \mathrm{g} \mathrm{CH}_{4} \cdot \mathrm{m}^{-2} \cdot \mathrm{d}^{-1}$ to $1,630 \mathrm{mg} \mathrm{CH}_{4} \cdot \mathrm{m}^{-2} \cdot \mathrm{d}^{-1}$, and decreased greatly from September to April (Fig. 2). At Sta. 3, methanogenesis was much lower than that at Sta. 2. The maximum value was only $23.4 \mathrm{mg} \mathrm{CH} \cdot \mathrm{CH}^{-2} \cdot \mathrm{d}^{-1}$. This value is smaller than the maximum methane release from salt marsh in Barataria Basin (ca. $49 \mathrm{mg}$ $\left.\mathrm{CH}_{4} \cdot \mathrm{m}^{-2} \cdot \mathrm{d}^{-1}\right)$ (DeLaune, et al., 1983) and is nearly in the lower range $\left(20-1,000 \mathrm{mg} \mathrm{CH}_{4}\right.$. $\mathrm{m}^{-2} \cdot \mathrm{d}^{-1}$ ) of anoxic coastal marine sediments reported by CRILL and Martens (1983).

To evaluate environmental factors controlling methanogenesis at three stations in the lower Tama River, the correlation matrix between methanogenesis and environmental factors examined at each station was calculated (Table 3).

In the $0 \sim 4 \mathrm{~cm}$ sediment layer at Sta. 1 , the methanogenesis measured at $30^{\circ} \mathrm{C}$ incubation was correlated only with TOC in interstitial water $(\mathrm{p}<0.01)$, and the methanogenesis at in 
Table 3. (a) Correlation matrix between methanogenesis and environmental factors at Sta. $1 . n=16$

\begin{tabular}{lcccccrr}
\hline & MT & TEM & IL & TOC & SO4 & EH & EC \\
\hline M30 & $0.774^{* * *}$ & 0.087 & -0.088 & $0.648^{* *}$ & -0.102 & -0.485 & 0.230 \\
MT & & $0.615^{*}$ & -0.025 & 0.357 & -0.205 & -0.453 & -0.125 \\
TEM & & & 0.031 & -0.039 & -0.309 & -0.197 & -0.379 \\
IL & & & 0.168 & -0.130 & 0.060 & -0.291 \\
TOC & & & & 0.036 & -0.234 & -0.141 \\
SO4 & & & & & & $0.676^{* *}$ & -0.137 \\
EH & & & & & & & -0.184 \\
\hline
\end{tabular}

M30 : methanogenesis at $30^{\circ} \mathrm{C}, \mathrm{MT}:$ methanogenesis at in situ temperature, TEM : in situ temperature, IL : ignition loss of sediments, TOC : total organic carbon in interstitial water, SO4 : sulfate concentration in interstitial water, $\mathrm{EH}$ : sediment redox potential at the depth of $1 \mathrm{~cm}$, and $\mathrm{EC}$ : electric conductivity of river water.

${ }^{* * *}: 0.1 \%,^{* *}: 1 \%,^{*}: 5 \%$ confidence level.

Table 3. (b) Correlation matrix between methanogenesis and environmental factors at Sta. 2. $n=14$

\begin{tabular}{lccccccc}
\hline & MT & TEM & IL & TOC & SO4 & EH & EC \\
\hline M30 & $0.925^{* * *}$ & 0.387 & $0.706^{* *}$ & 0.400 & -0.515 & $-0.650^{*}$ & -0.386 \\
MT & & 0.507 & $0.568^{*}$ & 0.352 & -0.470 & $-0.617^{*}$ & -0.338 \\
TEM & & & -0.127 & -0.186 & $-0.575^{*}$ & -0.390 & $-0.595^{*}$ \\
IL & & & & 0.427 & -0.175 & -0.343 & -0.067 \\
TOC & & & & & -0.406 & -0.377 & -0.443 \\
SO4 & & & & & 0.274 & $0.925^{* * *}$ \\
EH & & & & & & 0.370 \\
\hline
\end{tabular}

Symbols are the same as those in (a).

Table 3. (c) Correlation matrix between methanogenesis and environmental factors at Sta. 3. $n=9$

\begin{tabular}{|c|c|c|c|c|c|c|c|}
\hline & MT & TEM & IL & TOC & $\mathrm{SO} 4$ & $\mathrm{EH}$ & $\mathrm{EC}$ \\
\hline M30 & $0.854^{* *}$ & -0.596 & 0.170 & -0.489 & 0.583 & 0.382 & 0.664 \\
\hline MT & & -0.181 & 0.322 & -0.564 & 0.154 & 0.015 & 0.240 \\
\hline TEM & & & -0.030 & 0.315 & $-0.820^{* *}$ & $-0.862^{* *}$ & $-0.819^{* *}$ \\
\hline IL & & & & -0.205 & -0.311 & -0.368 & -0.227 \\
\hline TOC & & & & & -0.131 & -0.259 & -0.049 \\
\hline $\mathrm{SO} 4$ & & & & & & $0.841^{* *}$ & $0.947^{* * *}$ \\
\hline $\mathrm{EH}$ & & & & & & & 0.734 \\
\hline
\end{tabular}

Symbols are the same as those in (a).

Table 3. (d) Correlation matrix between methanogenesis and environmental factors at three stations.

\begin{tabular}{|c|c|c|c|c|c|c|c|}
\hline & MT & TEM & IL & TOC & $\mathrm{SO} 4$ & $\mathrm{EH}$ & $\mathrm{EC}$ \\
\hline M30 & $0.869^{* * *}$ & 0.147 & $0.332^{*}$ & $0.360^{*}$ & $-0.585^{* * *}$ & $-0.616^{* * *}$ & $-0.537^{* * *}$ \\
\hline MT & & $0.435^{* *}$ & 0.295 & 0.286 & $-0.498^{* *}$ & $-0.569^{* * *}$ & $-0.451^{* * *}$ \\
\hline TEM & & & -0.066 & -0.055 & -0.238 & -0.294 & -0.287 \\
\hline IL & & & & 0.256 & -0.145 & -0.170 & -0.124 \\
\hline TOC & & & & & -0.093 & -0.163 & -0.100 \\
\hline $\mathrm{SO} 4$ & & & & & & $0.840^{* * *}$ & $0.977^{* * *}$ \\
\hline $\mathrm{EH}$ & & & & & & & $0.829^{* * *}$ \\
\hline
\end{tabular}

Symbols are the same as those in (a). 
situ temperature was correlated only with the temperature $(\mathrm{p}<0.05)$. No other correlation was observed between the methanogenesis and the environmental factors examined. In the $0 \sim 6$ $\mathrm{cm}$ sediment layer at Sta. 2, the methanogenesis measured at both $30^{\circ} \mathrm{C}$ and in situ temperature was correlated with organic matter content of sediment ( $\mathrm{p}<0.01$ and $\mathrm{p}<0.05$, respectively) but not with TOC in interstitial water. Although no negative correlation was found between the methanogenesis and the sulfate concentration in interstitial water at less than $5 \%$ confidence level, the methanogenesis was lower than 0.7 $\mathrm{mmol} \cdot \mathrm{m}^{-2} \cdot \mathrm{d}^{-1}$ at the sulfate level higher than 2 $\mathrm{mM}$. In such sediments, methanogenesis seemed to be inhibited by sulfate reduction which was controlled by seawater inflow, based on the results of the effect of sulfate or molybdate addition to the sediment slurries (Table 2). Interstitial water seemed to be rapidly exchanged with river water, because there was a strong correlation $(\mathrm{p}<0.001)$ between conductivity of river water and sulfate in interstitial water. At Sta. 2, sulfate concentration in river water often fluctuated in a short period according to tidal cycle (Kanagawa Prefecture, 1985). From the above results, both methanogenic bacteria and SRB may have been potentially active, and dominancy in anaerobic respiration may have changed rapidly between them according to fluctuating availability of sulfate. In poor sulfate conditions, SRB might have been under association with methanogenic bacteria as shown by Bryant et al. (1977) in twomembered cultures.

In the $0 \sim 14 \mathrm{~cm}$ sediment layer at Sta. 3, the methanogenesis measured at both $30^{\circ} \mathrm{C}$ and in situ temperature was not correlated with any environmental factors examined at $5 \%$ confidence level. Although sulfate reduction probably inhibited methanogenesis competitively, the degree of inhibition might be low at low temperatures, as shown in the slurry experiments in February 1986 (Table 2). In this connection, the sulfate concentration in the deep layer $(12 \sim 14 \mathrm{~cm})$ was low $(6.5 \sim 10.3 \mathrm{mM})$ in summer and high $(12.1 \sim 19.6 \mathrm{mM})$ in winter. However, Westermann and Ahring (1987) re- ported that methanogenesis was more sensitive to temperature change than sulfate reduction in a European swamp. Further studies are needed to evaluate the effects of temperature on the interaction between methanogenesis and sulfate reduction.

From the correlation matrix for the data from the three stations together, the methanogenesis at in situ temperature was correlated positively with temperature $(p<0.01)$ and negatively with sulfate level in interstitial water $(\mathrm{p}<0.01)$.

The numbers of methanogenic bacteria at Stas. 1 and 2 were similar to those in sediments of eutrophic Lake Vechten (CAPPENBERG, 1974) and of River Saal (ZAISs, 1981). The numbers at Sta. 3 were smaller than those in salt marsh and estuarine sediments reported by JONES and Paynter (1980) and Franklin et al. (1988). The numbers of methanogenic bacteria in the $0 \sim 4$ $\mathrm{cm}$ layer at Sta. $1(n=11)$ and the $0 \sim 14 \mathrm{~cm}$ layer at Sta. $3(n=8)$ were not correlated with the methanogenesis and any environmental factors examined, but in the $0 \sim 6 \mathrm{~cm}$ layer at Sta. $2(n=10)$ the numbers showed correlations with the methanogenesis $(p<0.001)$ and organic matter content $(p<0.05)$. The number of methanogenic bacteria might be a rate-limiting factor at Sta. 2, but not at Stas. 1 and 3. It was notable that the numbers of SRB were correlated with those of methanogenic bacteria at brackish stations (Stas. 2 and $3, p<0.05$ ), in spite of the competitive relationship between the two bacterial groups.

\section{Acknowledgements}

I am grateful to Dr. D. B. NEDwell, University of Essex, for his critical reading of the early draft and to M. Fukui, N. Takahashi, and E. KoKUBUGATA for their assistance in this work. I also thank the Tokyu Foundation for Better Environment and the Nissan Science Foundation for support of this work. 


\section{摘 要}

多摩川の污濁下流域底泥堆積物における メタン生成

多摩川の污濁下流域 3 地点の底泥堆積物におけ るメタン生成と環境因子, 細菌数の季節変化を調 査した。メタン生成は淡水域で最も高く, 間隙水 中の硫酸イオン濃度が増加する下流ほど低かった。 3 地点ともメタン生成は春から夏に高く, 冬に低 下するが，最下流では例外もみられた。メタン生 成活性が最大を示す堆積物層は下流ほど深くなる 傾向があった。

底泥眯濁液に各種の基質, 硫酸塩およびモリブ デン酸塩を添加してメタン生成に対する影響を調 べたところ, メタン生成は硫酸還元によって拮抗 的に阻害されるが, 阻害の程度は間隙水中の硫酸 イオン濃度が低い場合に低下することが示された。

メタン生成と環境因子との関係について考察し た。

\section{References}

American Public Health Association (1971): Standard Methods for the Examination of Water and Wastewater, 15th ed., American Public Health Association, Washinton, D. C.

Bryant, M. P., L. L. Campbell, C. A. Reddy, and M. R. CRABILL (1977): Growth of Desulfovibrio in lactate or ethanol media low in sulfate in association with $\mathrm{H}_{2}$-utilizing methanogenic bacteria. Appl. Environ. Microbiol., 33; 11621169.

CAPPEnBerg, T. E. (1974): Interrelations between sulfate-reducing and methane-producing bacteria in bottom deposits of a fresh-water lake. I. Field observations. Antonie van Leeuwenhoek, 40; 285-295.

Crill, P. M. and C. S. Martens (1983): Spatial and temporal fluctuations of methane production in anoxic coastal marine sediments. Limnol. Oceanogr., 28; 1117-1130.

Delaune, R. D., C. J. Smith, and W. H. Patrick, JR. (1983): Methane release from Gulf coast wetland. Tellus, 35B; 8-15.

Franklin, M., W. J. Wiebe, and W. B. Whitman (1988): Populations of methanogenic bacteria in a Georgia salt marsh. Appl. Environ. Microbiol., 54; 1151-1157.

Hanya, T. (1960): Methods for Water Analyses, Maruzen, Tokyo (in Japanese).

Holdemann, L. V. and W. E. C. Moore (1975):
Anaerobe Laboratory Manual, 3rd ed., Virginia Polytechnic Inst. \& State Univ., Virginia.

Howard, D. L., J. I. Frea and R. M. Pfiester (1971): The potential for methane-carbon cycling in Lake Erie. Proceedings, 14th Conference, Great Lakes Research, 463-473.

Iannotti, E. L., P. Kafkewitz, M. J. Wolin and M. P. BRYANT: Glucose fermentation products of Ruminococcus albus grown in continuous culture with Vibrio succinogenes: changes caused by interspecies transfer of $\mathrm{H}_{2}$. J. Bacteriol., 114; 1231-1240.

INGVORSEN, K. and T. D. BRock (1982): Electron flow via sulfate reduction and methanogenesis in the anaerobic hypolimnion of Lake Mendota. Limnol. Oceanogr., 27; 559-564.

Jones, W. J. and M. J. B. PAynter (1980): Populations of methane-producing bacteria and in vitro methanogenesis in salt marsh and estuarine sediments. Appl. Environ. Microbiol., 39; 864-871.

JøRGENSEN, B. B. (1977): The sulfur cycle of a coastal marine sediment (Limfjorden, Denmark). Limnol. Oceanogr., 22; 814-832.

Kanagawa Prefecture (1985): Annual Report on Water Quality, p.44-45, Kanagawa Prefecture, Yokohama (in Japanese).

Kiene, R. P. and D. G. CAPOnE (1985): Degassing of pore water methane during sediment incubations. Appl. Environ. Microbiol., 49; 143-147.

Kristjansson, J. K., P. Schönheit and R. K. THAuER (1982): Different $K_{s}$ values for hydrogen of methanogenic bacteria and sulfate reducing bacteria : An explanation for the apparent inhibition of methanogenesis by sulfate. Arch. Microbiol., 131; 285-288.

LAANBRoEK, H. J. and H. VELDKAMP (1982): Microbial interlactions in sediment communities. Phil. Trans. R. Soc. London, B 297; 533-550.

Lovley, D. R., D. F. Dwyer and M. J. Klug (1982): Kinetic analysis of competition between sulfate reducers and methanogens for hydrogen in sediments. Appl. Environ. Microbiol., 43; 13731379.

Lupton, F. S. and J. G. Zeikus (1984): Physiological basis for sulfate-dependent hydrogen competition between sulfidogens and methanogens. Current Microbiol., 11; 7-12.

Mountfort, D. O., R. A. Asher, E. L. Mays and J. TIEDJE (1980): Carbon and electron flow in marsh and sandflat intertidal sediments at Delaware Inlet, Nelson, New Zealand. Appl. Environ. Microbiol., 39; 686-694. 
Nedwell, D. B. (1984): The input and mineralization of organic carbon in anaerobic aquatic sediments. Adv. Micro. Ecol., 7; 93-131.

OGurA, N. (1978): Organic matter and its decomposition in a bay. Marine Sci., 10; 807-812 (in Japanese).

Oremland, R. S. and B. F. TAyler (1978): Sulfate reduction and methanogenesis in marine sediments. Geochim. Cosmochim. Acta, 42; 209214.

PECK, H. D. (1959): The ATP-dependent reduction of sulfate with hydrogen in extracts of Desulfovibrio desulfuricans. Proc. Nat. Acad. Sci. U. S. A., 45; 701-708.

Phelps, T. J. and J. G. Zeikus (1985): Effect of fall turnover on terminal carbon metabolism in Lake Mendota sediments. Appl. Environ. Microbiol., 50; 1285-1291.

Robinson, J. A. and J. M. Tiedje (1984): Competition between sulfate-reducing and methanogenic bacteria for $\mathrm{H}_{2}$ under resting and growing conditions. Arch. Microbiol., 137; 2632.

Sayama, M. and Y. Kurihara (1984): Characteristics of decomposition of organic matter in an estuary, p.111-143. In Microbial Ecology 12 (Society for the Study of Microbial Ecology ed.), Gakkai Shuppan Center, Tokyo (in Japanese).

Scholkovitz, E. R. (1978): Flocculation of dissolved organic matter during the mixing of river water and seawater. Geochim. Cosmochim. Acta, 40;831-845.

Schönheit, P., J. K. KRISTJAnsson and R. K. Thauer (1982): Kinetic mechanism for the ability of sulfate reducers to out-compete methanogens for acetate. Arch. Microbiol., $132 ; 285-288$.

Senior, E. E., E. B. Lindstrom, I. M. Banat and D.

B. Nedwell (1982): Sulfate reduction and methane production in the sediment of a saltmarsh on the east coast of the United Kingdom. Appl. Environ. Microbiol., 43; 987-996.

ShigA, I. (1983): Sulfides, p.70-76. In AnalyticalMethods for Soil Nutrients (Committee forAnalysis of Soil Nutrients ed.), Yohkendo, Tokyo (in Japanese).

Smith, R. L. and M. J. KLUG (1981): Electron donors utilized by sulfate-reducing bacteria in eutrophic lake sediment. Appl. Environ. Microbiol., 42; $116-121$.

Sørensen, J., D. Christensen and B. B. Jørgensen (1981): Volatile fatty acids and hydrogen as substrates for sulfate reducing bacteria in anaerobic marine sediment. Appl. Environ. Microbiol., 42; 5-11.

Tezuka, Y. (1979): Distribution of sulfate-reducing bacteria and sulfides in aquatic sediments. Jap. J. Ecol., 29; 95-102.

WARD, D. M. and M. R. Winfrey (1985): Interactions between methanogenic and sulfate-reducing bacteria in sediments. Adv. Aquat. Microbiol. 3; 141-179.

Westermann, P. and B. K. Ahring (1987): Dynamics of methane production, sulfate reduction, and denitrification in a permanently waterlogged alder swamp. Appl. Environ. Microbiol., 53; 2554-2559.

ZAIss, U. (1981): Seasonal studies of methanogenesis and desulfurication in sediments of the River Saar. Zentralbl. Bakteriol. Mikrobiol. Hyg. Abt. I, Orig. C 2; 76-89.

(著者: 滝井 進, 東京都立大学理学部生物学教室, 干 158 東京都世田谷区深沢 2-1-1 ; Susumu TAKII, Department of Biology, Faculty of Science, Tokyo Metropolitan University)

Received : 21 April 1989

Accepted : 15 June 1989 